\title{
Digital Cohesion in Era of Pandemic COVID-19 in Indonesia
}

\author{
Iwan Henri Kusnadi ${ }^{1}$, M Dian Hikmawan ${ }^{2 *}$ \\ ${ }^{1}$ Faculty of Administration, Universitas Subang, 41285-Indonesia. \\ ORCID: 0000-0001-7556-8029. \\ $2^{2 *}$ Faculty of Social and Political Science, Universitas Sultan Ageng Tirtayasa, 41285-Indonesia. \\ ORCID: 0000-0002-9554-8882.
}

\begin{abstract}
Pandemic Covid-19 is a very precarious phenomenon that we face today, no country is ready to face this pandemic. With so many countries plagued by this Covid-19 and also several victims from the dangers of this virus, it makes all fundamental changes both economically and socially. Indonesia is facing the pandemic covid-19 with no ease, but what interesting is how cohesion is emerging both in the digital world that is everyday social media and also volunteers present in various aspects. This research looks with a focus on how the digital cohesion that arise from existing and fundamental communities rises together both in the social media and volunteer communities. This research shows that digital cohesion can be built by communities both in the digital world through social media and communities that already have a strong background in society.
\end{abstract}

Keywords: Covid-19, Digital Cohesion, Volunteerism, Indonesia

\section{INTRODUCTION}

Covid-19 (Coronavirus Disease 19) became a concern to the world today, Covid-19 in a short time shook all stability both the world economy and politics. In a time of uncertain and full concern for most countries and citizens of the world. Covid19 raises many economic and social problems. One of them is in Indonesia. The increasing spread of this virus every day makes the government and the Indonesian community take many steps to overcome this problem. All the steps that were taken by the state certainly have a very big impact on the lives of its citizens. The biggest problem in the policy taken by the government with PSBB (Large-Scale Social Limitation) is the reduction in both social and economic activities in the daily life of its citizens.

With this phenomenon and the policies that have been taken, resulting in socio-economic activities of citizens to be hampered even widespread and cause increasingly complex problems. With the more than a half economic structure supported by the informal economy. This creates problems in the social and economic fields.

Under conditions of uncertainty and increasing unemployment due to work termination also laying off the working class with a very large number of about two million workers who lost their jobs according to the Ministry of Labor as of March 24, 2020 (Kompas.com) in a short time starting in March while in April, of course, this has become a complexity for countries everywhere in tackling the socio-economic impacts caused by
Covid-19. The existing social problems with all the efforts made by the Indonesian government will not be able to cope with this big problem. Therefore, from the phenomena that have arisen lately, we can see that the problems and impacts caused by the Covid-19 pandemic arouse a race of solidarity among Indonesians and Indonesian people to share in confronting the Covid-19 pandemic.

The social solidarity that arises among the people is certainly interesting to study, digital society (digital citizenship) turns out to be able to be a driving force for the emerge of mass social solidarity. This condition spread not only on a national scale even to the regions in Indonesia. Even this condition leads to thinking and how to behave in a society that tends to be pessimistic because of the rolling of new problems that lead to the concerns of individual human beings, families, and communities about the fate of their lives. This certainly shows us all where it turns out that in the face of a very big and complicated problem, a democratic country shows that social power that is built can at least provide hope and strength in the face of disasters (Hikmawan, 2020). This social solidarity becomes the main capital in seeing how the social relations that are built by Indonesian people are. This attachment and concern are seen in the activities of its citizens who try to become social agents who can have a wide impact in times of uncertainty (Hikmawan, 2020).

This research specializes in looking at how social cohesion is present in the form of social solidarity built by many Indonesian people, both through social media and on a community basis. Besides that, seeing how solidarity is manifested in forms of volunteerism and social relations is interesting to study because it can be a good pattern for the development of the active citizenship (Mouffe, 1993) as a new form of the democratic state in which state warehouses participate in build and define the quality of democracy in their own country (Hikmawan, 2017).

\section{LITERATURE REVIEW}

\subsection{Community and Covid 19}

Citizens are essentially a community wherein a country's citizens become a center in the distribution of power. During the Covid-19 pandemic, it made us realize that this problem is not a problem that is only the duty of the state, but there is also the responsibility of fellow citizens in helping to solve the problem of Covid-19. Social solidarity is the key to understanding what others have to do. As an active citizen, in a democratic country not only presupposes how the country 
can meet the needs of its citizens but further how every citizen can build a strong community that can be a collective action together (Isin, 2009). In this case, citizens are not only objects for statehood but are subject to the emerge of the meaning of a country's rise (Hikmawan, 2020).

The community becomes very important in building social cohesion that can respond to problems from the basics and realities that occur in their daily lives. One-sided community as a dominant form that can make a change in situations that may be difficult to change (Anderson, 1991). In seeing both social and economic consequences caused by a covid-19 pandemics, the community can be seen as an alternative way to overcome the problems that arise (Brillantes \& Fernandez, 2012). In this case, the community becomes an important role because in addition to the issue of empowering the community apart from that there is trust and engagement that makes a community strong and able to solve existing problems (Hikmawan, 2017). The real challenge we face also concerns demographic bonuses as the results of an economic analysis published by the Ministry of Education and Culture (2013) that the Indonesian nation will receive a demographic bonus as Indonesia's social capital in 2045. What about the social community of Indonesian citizens in 2045? The dynamic process of social solidarity generally requires time and effort and struggle.

\subsection{Actors and Social Engagement}

Social solidarity can be interpreted as an effort to build mutual independence, not to isolate some citizens and prioritize other citizens, but in critical reflection, social solidarity is always present in situations where uncertainty is present in the activities of fellow citizens. The Covid-19 pandemic has tested all citizens in various parts of the world including Indonesia. According to Emile Durkheim, (Durkheim, 1982) Social solidarity can at least emerge in two categories, namely mechanistic solidarity in which solidarity is generated by a powerful driving machine in which solidarity is the theme in his political discourse, and the second is organic solidarity, where this model shows solidarity that built on the awareness as citizens of each other.

In a scheme, why social solidarity can be generated in a relationship or interaction of the community, of course, many things that make it. Among them can be seen in the picture.

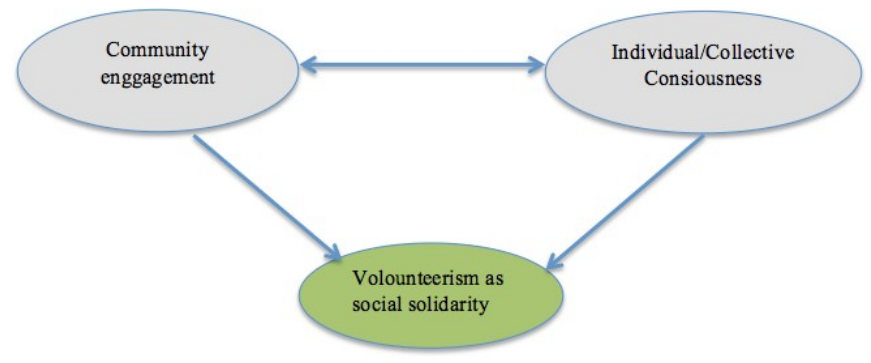

Source: (Kusnadi and Hikmawan, 2020)

Seen from that scheme, it appears that in the process of social solidarity not only the role of one or two people is formed but it becomes a shared awareness that turns into joint action in the face of something.

Social cohesion is a theme where social cohesion is considered as an alternative to a problem that occurs. Social cohesion is a movement that comes from the community where each member of the community is encouraged to interact with each other in achieving something that is a common goal (Schmitt, 2000). One-sided social cohesion is an alternative that is considered capable of arousing the community as networks that are expected to be able to solve a problem that is around it. The basis of social cohesion is society itself. Citizenship with each other can compete and able to make a breakthrough to respond to problems (UNDP, 2015).

Table 1. Social Cohesion Framework

\begin{tabular}{|l|l|l|}
\hline SOCIAL RELATIONSHIPS & CONNECTEDNESS & $\begin{array}{l}\text { ORIENTATION TOWARDS THE } \\
\text { COMMON GOOD }\end{array}$ \\
\hline $\begin{array}{l}\text { Social networking: Quality and quantity } \\
\text { of social relationships and social networks. }\end{array}$ & $\begin{array}{l}\text { Feeling of belonging: Self- perception } \\
\text { as a member of a group, sense of shared } \\
\text { identity. }\end{array}$ & $\begin{array}{l}\text { Social responsibility: } \\
\text { Defending the interests of society even } \\
\text { at the expense of one's own objectives } \\
\text { and needs. }\end{array}$ \\
\hline $\begin{array}{l}\text { Participation: Political participation (e.g. } \\
\text { voting in elections) and socio-cultural } \\
\text { participation (civic involvement in } \\
\text { associations, volunteer work). }\end{array}$ & $\begin{array}{l}\text { Identification: Identification with a } \\
\text { region, federal state, nation, Europe, } \\
\text { belonging rated as important aspect of } \\
\text { personal identity. }\end{array}$ & $\begin{array}{l}\text { Solidarity: Cooperation and support for } \\
\text { fellow-citizens. }\end{array}$ \\
\hline $\begin{array}{l}\text { Trust: General trust in one's fellow human } \\
\text { beings and political institutions. }\end{array}$ & & $\begin{array}{l}\text { Recognition of the social order and } \\
\text { social rules/anomie: Respect for social } \\
\text { institutions and adherence to the rules } \\
\text { of communal life (as well as the rules } \\
\text { for changing the social order) vs. } \\
\text { disregard and transgression of norms. }\end{array}$ \\
\hline $\begin{array}{l}\text { Acceptance of diversity: Intergroup } \\
\text { attitudes and tolerance towards minorities }\end{array}$ & & \\
\hline
\end{tabular}

Source : (UNDP, 2015) 


\section{METHODOLOGY}

The research method used in this research is a descriptive qualitative method. This type of research will produce descriptive data on oral and written words and the behavior or activities of the person or group under study. While the approach used is the phenomenological approach. Phenomenology is the choice of method that researchers use because phenomenology opens space for the research team in conducting research interpretations of the problems being studied. Phenomenology is used as a critical-reflective and interpretive analysis of a social phenomenon (Padilla-Díaz, 2015).

A literature study also conducted on several digital citizenship, social cohesion, and the Covid-19 pandemic. From the beginning of the emerging Covid-19, social media has a big role as one of the tools which connecting the citizens' activity. A lot of activities related to charity and fund rising held by many communities to help each other. Social media becomes an important variable that I used to be a research design.

Phenomenology as a method also allows researchers to retrieve and analyze all possibilities from the data that appears (Hikmawan, 2017). Eidetic reduction enables the researcher to make a conclusion based on a phenomenological awareness base and see it comprehensively from the problems that exist in social relations (Padilla-Díaz, 2015).

\section{RESULT AND DISCUSSION}

\subsection{Digital Citizen and Community in Pandemic Covid 19}

Netizens or digital society lately amid the rampant pandemic cases in Indonesia shows the other side of a social reality where we can see together the community through social media sharing to overcome the dynamics and complexity of existing problems. One example is what was done by Narasi $T V$ and Kompas $T V$ in raising funds for social action as tangible evidence of how the digital society was mobilized to alleviate and assist in the Covid-19 pandemic era.

The emergence of community in the digital world gives its color that makes major social and political changes. The digitalization of life in citizenship also takes on many roles in changing the life procedures of citizens. In the case of the covid-19 pandemics, the digital era is a very serious concern, where the spread of covid 19 with all its effects requires citizens to remain at home and stop all their usual daily activities (Isin, 2009). Of course, this has great consequences for citizens' social and economic activities. But this is not the case with the digital world, the internet has become a very reliable thing in the covid-19 pandemic period like this. The digital world has become a new social and economic activity with the covid-19 pandemics. With the rampant shifts made by people who are transforming into digital citizenship, digital is a way of seeing opportunities for solidarity and community built in an era that is as uncertain as covid-19.

Building a community with a shift from reality to digital reality became very interesting, but now that is developing. During the threat of a pandemic covid-19, digital reality as a way for new citizens to find gaps in changing times has proven to be effective and has a real impact on change and solving existing problems.

\subsection{Collective Awareness and Solidarity}

The most important picture in seeing how solidarity is realized is how solidarity is built very well. If you look at social media data, how the figures and many influencers built solidarity during the Covid-19 pandemic in various ways. Starting from making and opening donations in general also open charity concerts that are mostly made by influencers and entertainers in Indonesia.

In the research conducted by Kustiningsih and Nurhadi 2020 in Covid-19 Handling Management in Indonesia explained that how social media became one of the milestones in helping to make awareness about covid-19 (Mas'udi \& Winanti, 2020). There are at least two things: first, increasing the digital literacy power of the community to survive the COVID-19 pandemic; and second, the strengthening of social capital through social solidarity actions. In these two cases we see that social media is the basis of how cohesion and solidarity can be generated in understanding and responding to covid-19 pandemics.

Strengthening digital literacy became interesting and increased in the era of the Covid-19 pandemic. Digital literacy also became one of the very strong bases embedded in spreading understanding about handling and at the same time building social solidarity that became a driving force in responding to the covid-19 pandemic in Indonesia. Besides that, what happened in measuring the extent to which the existing actors were mapped in response to the covid-19 handling. There are at least two big actors who give great attention as movers in social media as a basis for generating joint solidarity, namely the government and non-government sectors, for the government sector, how the role of apparatus is maximized as a driving force and not infrequently many political figures became a driving force like what happened to the Governor of West Java Ridwan Kamil who made many breakthroughs with various applications and complaints online in response to the pandemic covid-19. For nongovernmental actors, there are many ranging from NGOs, nongovernmental organizations to the communities that reach the lowest strata.

This non-governmental actor has strong social capital in building social solidarity and cohesion in society. Nongovernmental actors have grassroots networks that can enter into various layers of society. We can learn a lot from Aksi Cepat Tanggap (ACT) and the Indonesian Red Cross (PMI). Institutions that have a base to the lowest strata of the community have many important roles in making social awareness and also a bridge in channeling all forms of social assistance. Non-governmental institutions are also strong agents such as the synergy of the solidarity community in political, social, and economic infrastructure such as the role of companies, television media, community activists, and actors concerned with social organizations and even religious education even young people. 


\subsection{The Emerge of Volunteers as a Social Cohesion Phenomenon}

From the research conducted (Supriyati, 2020) in the handling of covid-19 management in Indonesia explained that how volunteers in the covid-19 pandemic periods became a social responsibility for each individual in actualizing themselves as an expression of social solidarity (Mas'udi \& Winanti, 2020). At least the volunteers of the pandemic covid-19 made a major manifestation of how solidarity can be seen immediately as a form of real solidarity in responding to the consequences of the covid-19 pandemics.

If we see and refer to what is the role of a volunteer is as follows. According to the COVID-19 Medical and Community Health Handling Quick Guidelines, there are six roles expected by COVID-19 volunteers (Task Force for the Acceleration of COVID-19 handling, 2020). The six roles are:

1. Help spread accurate information to the public

2. Helps educate and provide psychological support in reduce public panic during the COVID-19 outbreak

3. Help organize and direct the community in need information related to test flow and action flow, both in the community and in hospitals

4. Helps in monitoring and providing the information needed by OTG and ODP that carry out quarantine

5. Help channel the basic needs of the community especially for OTG and ODP in-home quarantine, as well as for vulnerable groups

6. For medical volunteers, they can provide support to doctors, nurses, hospital officials, ambulance officers, etc. Trained medical volunteers if needed can carry out preventive education and rapid tests to OTG groups in public facilities using PPE (masks and gloves) and test results are reported through reporting mechanisms (Mas'udi \& Winanti, 2020).

Indonesian people are accustomed to living in communal life both formally and informally. The group is one of the important social capital in Indonesia. The power of groups can encourage togetherness to solve problems, including corona disasters. Group participation is needed to build collective strength against the plague. Building individual awareness in community groups is important to break the chain of distribution of corona. Here, it takes the role of opinion leaders to build awareness and change behavior to support corona disaster management. For example, reminding each other to obey the protocol to prevent the spread of the virus to the smallest neighborhood group. Also, the group's role is to strengthen the community's mental immunity so as not to experience an outbreak of anxiety due to corona.

Furthermore, networking between groups must be strengthened to build greater strength. Network groups without barriers and boundaries will more effectively unite a variety of different interests for the same interests: tackling the covid-19 pandemic disasters in Indonesia.

\section{CONCLUSION}

In seeing the covid-19 pandemic, citizenship in Indonesia as a community has given a very diverse color in addressing and responding to the existing social and economic impacts. At least this research can show three aspects that form the basis of how the community as a basis that contributes to responding and solving the problem of pandemic covid-19. The most important is community-based how solidarity and rise in various aspects, especially in social media or digital citizenship and digital literacy. Also, the basis that is not less is the resurrection of volunteerism that is present in various aspects, ranging from an active volunteer as an actor who comes down directly or as a secondary actor that has sprung up with various kinds of donations and so on. All these factors make the formation of social cohesion in which the community or citizenship becomes the main actor in responding to problems that arise as a result of the covid-19 pandemic in Indonesia.

\section{REFERENCES}

[1] Anderson, B. (1991). Imagined Communities. Verso.

[2] Brillantes, A. B., \& Fernandez, M. T. (2012). Good Governance, Social Quality, and Active Citizenship: Gawad Kalinga in the Philippines. International Journal of Social Quality, 1(2), 19-30. https://doi.org/10.3167/ijsq.2011.010203

[3] Durkheim, E. (1982). The rules of sociological method. Social Theory Re-Wired: New Connections to Classical and Contemporary Perspectives: Second Edition. The Free Press. https://doi.org/10.4324/9781315775357

[4] Hikmawan, M. D. (2017). Pluralisme Demokrasi Politik di Indonesia. Journal of Governance, 2(2), 223-247. https://doi.org/http://dx.doi.org/10.31506/jog.v2i2.2678

[5] Hikmawan, M. D. (2020). Consensual Democracy: A Challenge for Differentiated Citizenship. International Journal of Innovation, Creativity and Change. www.ijicc.net (Vol. 11). Retrieved from www.ijicc.net

[6] https://www.bps.go.id/subject/6/ tenaga- kerja.html

[7] https://money.kompas.com/read/ 2020/04/23/174607026/dampak-covid-19-menakerlebih-dari-2-juta-pekerja-di-phk-dan-dirumahkan

[8] https://www.vox.com/coronaviruscovid19/2020/3/17/21180645/covid-19-coronavirussocial-solidarity-epidemic-pandemic-paid-leave-healthcare

[9] Isin, E. F. (2009). Citizenship in flux: The figure of the activist citizen. Subjectivity, 29(1), 367-388. https://doi.org/10.1057/sub.2009.25

[10] Mas'udi, W., \& Winanti, P. S. (Eds.). (2020). Tata Kelola Penanganan COVID-19 di Indonesia. Gadjah Mada University Press.

[11] Mouffe, C. (1993). The Return of the Political. Verso. 
International Journal of Engineering Research and Technology. ISSN 0974-3154, Volume 13, Number 7 (2020), pp. 1775-1779 (C) International Research Publication House. https://dx.doi.org/10.37624/IJERT/13.7.2020.1775-1779

[12] Padilla-Díaz, M. (2015). Phenomenology in Educational Qualitative Research: Philosophy as Science or Philosophical Science? International Journal of Educational Excellence, 1(2), 101-110. https://doi.org/10.18562/ijee.2015.0009

[13] Schmitt, R. B. (2000). Social Cohesion as an Aspect of the quality of Societies: Concept and Measurement.
Centre for Survey Research and Methodology (ZUMA). https://doi.org/10.1007/s00376-007-1049-y

[14] UNDP. (2015). SOCIAL COHESION FRAMEWORK social cohesion for stronger communities. Retrieved from https://www.sfeg.org/wpcontent/uploads/2017/02/SC2_Framework-copy.pdf 